\title{
Methodological Accounting Tools for the Evaluation of Intangibles Management in Research Institutions: Some Empirical Remarks
}

\author{
Pierluigi Catalfo \\ Department of Economics and Management, University of Catania, Catania, Italy \\ Email: pcatalfo@unict.it
}

Received 9 October 2012; accepted 25 August 2015; published 28 August 2015

Copyright (C) 2015 by author and Scientific Research Publishing Inc.

This work is licensed under the Creative Commons Attribution International License (CC BY). http://creativecommons.org/licenses/by/4.0/

\section{(c) (i) Open Access}

\begin{abstract}
Knowledge is primarily considered as powerful value producer. The dynamic relationship of university and society starts with the economic exploitation of research results, with the intention, on the one hand, to safeguard the equilibrium of financial resources to support academic activity on the other hand with the intention to sustain society and more specifically stakeholders' interests. University and precisely its departmental structure are increasingly involved in the implementation and improvement of strategies focusing on technological transfer and on the activity of managing internal intangible resources. This study, after considering the logic that inspires or should inspire models for the evaluation of knowledge creation and accountability through the intangible assets of academic departments and research centres, illustrates empirically the situation concerning the diffusion of immaterial resource management tools in a relevant research area in Italy.
\end{abstract}

\section{Keywords}

Knowledge, Intangibles, Management Accounting, Control, Guideline

\section{Research Institution. Knowing and Developing the Competitive Advantage}

The value and the contribution are generated by research entities, usually, links society, economic and institutional structures which transform results into concrete activities. It is clear that the core activity of research is to be identified in intangibles management and therefore in intellectual capital management. The logic of process management, therefore, consists in planning and controlling those intangibles employed in the effective achieve- 
ment of results. Thus, the methodological approach becomes necessary and decisive overall, thanks to the product of research institutions. This is new knowledge that, managing intellectual capital asset, consequently generates new knowledge. From a strictly economic point of view, the process of knowledge creation and exploitation constitutes unequivocally the way to build the competitive advantage both for research institutions and their demand, as well as for the direct and indirect recipients of their knowledge creation. Generally, knowledge is primary considered a powerful value producer. The knowledge generation process is certainly complex to codify and repeat; it is structured on human resources value. It undergoes the influence of the context conditions [1] and often returns on investments are postponed as a consequence of long-term intervals. On the other hand, everybody knows that the probability that investments are profitable without risk is very low [2].

These management processes, thus, tend to rationalize such paths, looking at items concerning repetition, through the logic of acquisition of improvement mechanisms, aimed at generating repeatable processes [3]. In such a context, inevitably, all the issues related to the representation of the process responding to managerial needs and those about measurability and repeatability, become strategic for running business.

Knowledge generation, as it is often a context operation, occurs in very different ways. The relationship between research innovation and society is traditionally mediated by the connection between research institutions, more specifically universities and the social economic environment; a relationship responding to a networking logic; a relational moment of strategic value, when knowledge creation and transfer mechanisms can take place based on the natural functional connection between the academic world and society. Such a determination is undoubtedly valid, both for the economic world at the macro and micro level and consequently for the whole of society.

\subsection{Knowledge and Innovation Process}

We definitively define knowledge as a resource, as an element of the system's wealth, as variable structuring formally the complexity of evolution routes and of innovation mechanisms [4]-[6]. Therefore, the problem of strategic identification and that of knowledge management rely on human resources management as "residence" of intellectual capital, in other terms to the most unrepeatable resources for research and value generation [7]. It is a problem of consciousness before and of management afterwards, a problem that cannot be solved without an evolutional process concerning these managerial skills, without a process which deals with research and the consolidation of new value. If this does not occur, the research institution will be relegated to exploit, in a mechanic way and over decreasing time, the value of its human resources. Most well known formulas of exploitation of human factor on the one hand pass through the selection activity and through that of direction and development of human resources on the other. Such a management vision has characterized the most recent theories on intellectual capital even if it would not be correct to create an axiom linking a careful human resources management and business success. This occurs as a consequence of the combination of two factors: on one hand the consciousness of the existence of energies and unexpressed capabilities internally, on the other, the alternation between a culture based on the execution of duties and a value based one. In this sense, the recognition and exploitation of human resources competences and skills could represent the chance to set free and develop those potentialities which are unexpressed due to existing limitation for each research institution. To approach the logic of value, for example, could already mean in itself to turn human capital to better account without giving up the freedom of research and without balancing the research finalism and the profitability logic. In real terms, this implies an adequate conception of both the organization and the institution functioning dynamic, and above all, it requires an informative accounting and reporting system to be enriched by new methodologies, able, on one hand, to overcome the limits in representation of management dynamics and on the other, from the "value perspective", to lead toward the creation and the management of new intellectual capital and new intangible assets. On the organizational side, implementing the value creation perspective means knowing and recognising all the available resources as well as their value dynamics, so to adapt the existing resources to a precise model necessary to generate new value inside the research entity. Thus, instead of constraining resources in standard assets, in such a value creation perspective, the effort lies in the adaptation of the asset configuration to resources, so as to let them fully express their productive skills. This type of organization, where human resources management tends to create value, has to create resource synergies to let individual talent, skills, competences, knowledge and know-how be expressed in an integrated and balanced system meant to pursue the objective of value [8] [9]. More specifically, once the organization has been defined, as in the case of the process of the crea- 
tion of department in Italian universities, its functioning system should be structured so as to start the system by feeding it adequately. In other terms, once the strategic-operational lines to be followed to produce value have been defined, proceeding through the alignment of short and long term objectives, it is necessary to start the system operative processes for research generation and the activation of the mechanism of Knowledge sharing and knowledge creation, that is to say to start up those mechanisms which provide the performance quality following both the profile of the innovation effectiveness and the profile of spontaneity.

\subsection{Intellectual Capital as an Attribute of the Organizational Dynamics}

In Research institutions, the exploitation of intangibles and of intellectual capital is based on the fundamental assumption that the centre of gravity lies in the functional bodies. It is here that, thanks to mechanisms of data processing, the junction of the whole decision making process, occurs. Therefore, the structure of the institutional body can be considered a "channel "collecting information and transmitting decisions to other branches. Thus, the research entity can be represented as a temporal input-output system, where results are determined both by external events and by the internal system so as it is structured in terms of organization and available resources. In such interpretative "modus”, the concept of system has necessarily to involve that of "transducer". Transduction becomes essential both for the functioning of the system and survival as well as for the activation of processes generating knowledge through the coordination of the organs (such as the department director, the administrative director the IT responsible etc.) that serve as channels of information transmission, data flow and internal knowledge are managed. This fundamental task, observable at the internal micro system level, in terms of managerial activity consists in treating information flows in order to activate the mechanisms of knowledge creation. The organizational transducer has a limited capacity to collect, elaborate and to transform information into decisions and it is employed in splitting this capacity among the control need, the management need and other needs. Considering the organization and its components as the transducer, does not exclude creativity as value and resource. Some internal elements even become autonomous and create "varieties". In this sense, the knowledge generator capability is able to produce results in terms of innovative changing and higher competitiveness. Such a consideration is confirmed by recent conceptions that assume, even for a social extent, the attitude of human resources and of intellectual capital to create value over time, as an active substance constituting that systemic transducer mentioned previously. Inevitably, the functionality of conceptualization on organizational dynamics inside the research entity becomes necessary to understand the dynamics of re-use and re-creation of resources and particularly to realize the management processes which connect, through an indissoluble bond, human resources, knowledge and intellectual capital for value creation. This evidence has been summarized by the expression "intellectual capital" that semantically reveals an old and latent interest for the intangible aspects of economics, in accordance with, for example, Stewart's intentions-one of the first intellectual who has pragmatically concentrated his attention on the item [10] [11]. In his study, dated June 1991, "Brain Power. How Intellectual Capital is becoming America's most valuable asset”, as it is already well-known, Stewart, introduced intellectual capital among the traditional concepts of business economics and defined intellectual capital as the results of summing up all the knowledge belonging to people inside the company and as the element able to generate a competitive advantage on the market. Initially, the terminology referring to intangibles and intellectual capital was used to describe the asset dimensions and the dynamic effect of this particular resource. Stewart, therefore, intends intellectual capital as an organization attribute. In intellectual capital management the process of sharing and control of knowledge resources should be considered as fundamental in order to generate new Intellectual Capital. Moreover, the organization structure dynamic should be well known, consequently management should be able to interpret and to transduce information flows relating them to the organization architecture.

\subsection{Implementing Organizational Capital through Human Capital}

Among the intellectual capital resources diffused inside the organisation of research institutions, there must be the type of knowledge which is sufficient to implement the organisational structure at least to make the processes linked to communication needs effective [12]. The actual management of research institutions, overall with reference to university departments, consider intellectual capital resources as systems which are sensitive to the temporal variable and thus, systems undergoing a pragmatic determination of the relation action/time. At 
first, on the basis of the external context, global goals should be defined. Secondly, the interpretation of the first step should be divided into sub-systems, creating "subordinated capabilities" to control and rule subsystems adequate to achieve partial objectives. Even top managers have some limits to respect; in any case the best manner to exploit this limited capacity consists in creating other skills in those subjects who are delegated powers and tasks differently specialized. Thirdly, the attention moves to the mechanism of feedback allowing interventions while proceeding, fixing decisional criteria at all levels. In short, human resources value and quality certainly influence the business development, the operational conditions and all the relations generating social integration among individuals and groups and all those factors determining conflicts. These assumptions are in accordance with the current meaning given to the resource system, both on the logical side and on the sociological one. It is a widespread belief that full commitment can be obtained just by sharing goals, strategies and priorities and therefore an active participation in the achievement of results. The organizational structure and human resources management become then, a way to exploit "human capital" and its potentialities, carrying out development through human resources [13]. In particular, the value of this approach can be appreciated by the means of tools and methodology, of a business economics nature, through which it is possible to identify the attitude towards knowledge creation [14], both for individuals and groups, especially when monitoring the activities continuously and when adjusting them on the basis of feedback in order to match expectations and results.

\section{Relevance of Individual Behavior in Managing Research Institute}

Breaking down the goals into partial and local ones, with reference to the management of resources and intellectual capital, the inevitable individual and group reactions arise internally, which generally influence all behavior value. Intangibles management in research institutions can obtain effective results [15] only if individuals' reactions and behavior and social pressures are in line with the objective needs of managerial control, in terms of intellectual capital and intangible asset correction, in the system which organizes and divides managerial objectives. It is clear that individual freedom and creativity are to be respected. To achieve such an alignment, the managerial model and Management style has to be adequate to let the people involved perceive that all management effectively tends to make the distribution of power, goals, mans and incentives more and more equal. Therefore, the management methodology the personnel influences learning processes, especially because if it is correctly applied it accelerates these processes allowing a balance between skills and global plan needs. In this sense, the dynamic of the University and society relationship, in fact, has for some time embarked on the economic exploitation of research results, with the intention, on one hand, of safeguarding financial resource balance system to support academic activity, traditionally structured and concentrated on producing value to be diffused, on the other hand with the intention to sustain the community's economic affairs. The constant process of change involving the Italian University system has lead to considering differently and perhaps more proactively, issues connected to research and to its use in the socio economic context for financing purposes [16] The creation of "departments" at Universities in Italy is due to the necessity to improve the use of intellectual capital resources available to be employed in research. Indeed, this process even if it is already codified, cannot be fully evaluated because of the reasons mentioned above. Notwithstanding this, it is possible to catch a glimpse of the trend of the Italian reform. Structures organized in departments nowadays constitute most of the research entities which operate in Italy, but their management seems to be still due to spontaneous acts and without any direction for achievement of specific and planned goals. Furthermore, University departments in particular, still have to decide on an approach with society looking for an allocation on a relational scale that, from start to finish, perceives them, for example, still as foreign from a rooted path, in the economic context, till the limit in which they play, experimentally, the role of "entrepreneurial universities" [17]. Cultural reasons and traditional diversities can certainly explain the phenomenon, but the disorganized and disorderly response of departmental structures makes business economists face some questions. There are two dimensions to the questions, on one hand, to the functioning dynamics, to the production model followed by many entities strategically relevant for the economic system and on the other hand, to methodological approaches. Both dimensions are fundamental for guaranteeing the scientific rigour of research and to creating a socio-political debate to which, nevertheless, business economics still does not participate with strength or wide vision. This area cannot be investigated by the means of monolithic schemes; a heterodox methodological approach is necessary. It becomes a specific competitive factor that, in some countries is a traditional development model, such as north American ones. 
Recurrences and General Elements for, a Model of Intellectual Capital Report, Construction for Research Entities: Between Control Exigencies and Accountability

As already stated, knowledge management of research entities and in particular of University departmental structures become a success factor in the current dimension of innovation and competitiveness. Despite the relevant value of the managerial use of intangible resources and the use of knowledge, specifically, in the innovative value creation process, most scientific institutions are not confident about using accounting methodological tools for the resources representations and for the variations dynamics of their value [18] [19]. As a strategic intangible resource in research institutions [20], knowledge should be something to measure and control [21], something to monitor in order to manage all the production process in order to contribute effectively to achieve competitiveness by innovations [22] [23].

The theme of intangibles representation, evaluation and control, that intercepts some determinant aspects related to the production of incremental value in the innovation process and especially sub process, such as generation of competencies, filing patents or know how exchange leaves wide gaps in the definition of management and control instruments in methodological terms. Following this perspective, management and control tools methodologically could have different structures [24]-[26] and they could be characterized depending on the institution's specific activities and organization specific task [27], keeping in mind even the diffused heterodoxy [28]-[30] in the methodological allocation of techniques and a substantial methodological anarchy, result of an evolving scientific path and a consequent lack of standards. Annual analysis and the interpretation of these elements certainly tend to the visibly improve of the quality of the managerial effort and to improve the control of the value generated in the process. In the complex geography of models for the representation of intellectual capital, [31]-[37] perhaps it is the case to propose, according to existing literature a direction which indicates some recurrent elements which are useful in structuring a model, that can be considered inalienable. In order to define such a model is it possible to assume as a driver of the model, the knowledge generation process, considering that the information generated by this model have complex finalities, among which, the entity accountability [38] in front of its stakeholders, emerges [39]-[43].

Finalities are principally connected to control then, but they are even related to the identification of interventions aimed at improving the knowledge structure and flows inside the organization. Therefore, the intellectual capital report can be based on a process model, describing knowledge improvement over time as internal cycle. In such a context, knowledge from a human, structural and relational dimension is to be seen contemporarily as input and output. Different types of intangibles are represented by quantitative and qualitative indicators and target parameters are assigned when possible [44] [45].

Relations among single indicators and their variations are accompanied by a description. Value changes compared to the ones of a previous level clearly aim at illustrating the "control bond" and the causes and effects relationship to make strategic finalities comprehensive and communicable. The use of indicators generates the possibility, at first, to show individual values compared to the previous period.

This is the first step towards internal and external benchmarking. Thus, in an abstract key a model of intellectual capital report, starting by knowledge management, promotes the means for the strategic comprehension and for the evaluation of management paths and results. In particular, from an abstract path of the methodological panorama, some important positions can be considered. A possible scheme for a report model can be observed by following this path.

As a theoretical guideline model, in the schematization abovementioned (Figure 1), knowledge objectives are connected to corporate finalities related to the typical activity of the research institution. The guideline model is structured to integrate three dimensions. The three dimensions taken into account for the guideline model are: the knowledge dimension; the knowledge correlated structural asset dimension; the intellectual capital dimension [49].

Considering the need to manage knowledge as primary and determinant asset for Research institution, Knowledge objectives can be considered the first dimension. This dimension, relevant for the value production of Research institution, involves capital investment, financial and economic result and obviously can be observed traditionally through the system of value variance as is done in financial or managerial accounting. This can be considered as a structural asset dimension involved in the knowledge management process. Knowledge objectives, as shown in the model, can be broken down as a category of items in order to be observed and managed analytically, paying attention to: knowledge exploitation; effort to research excellence; staff promotion; network 


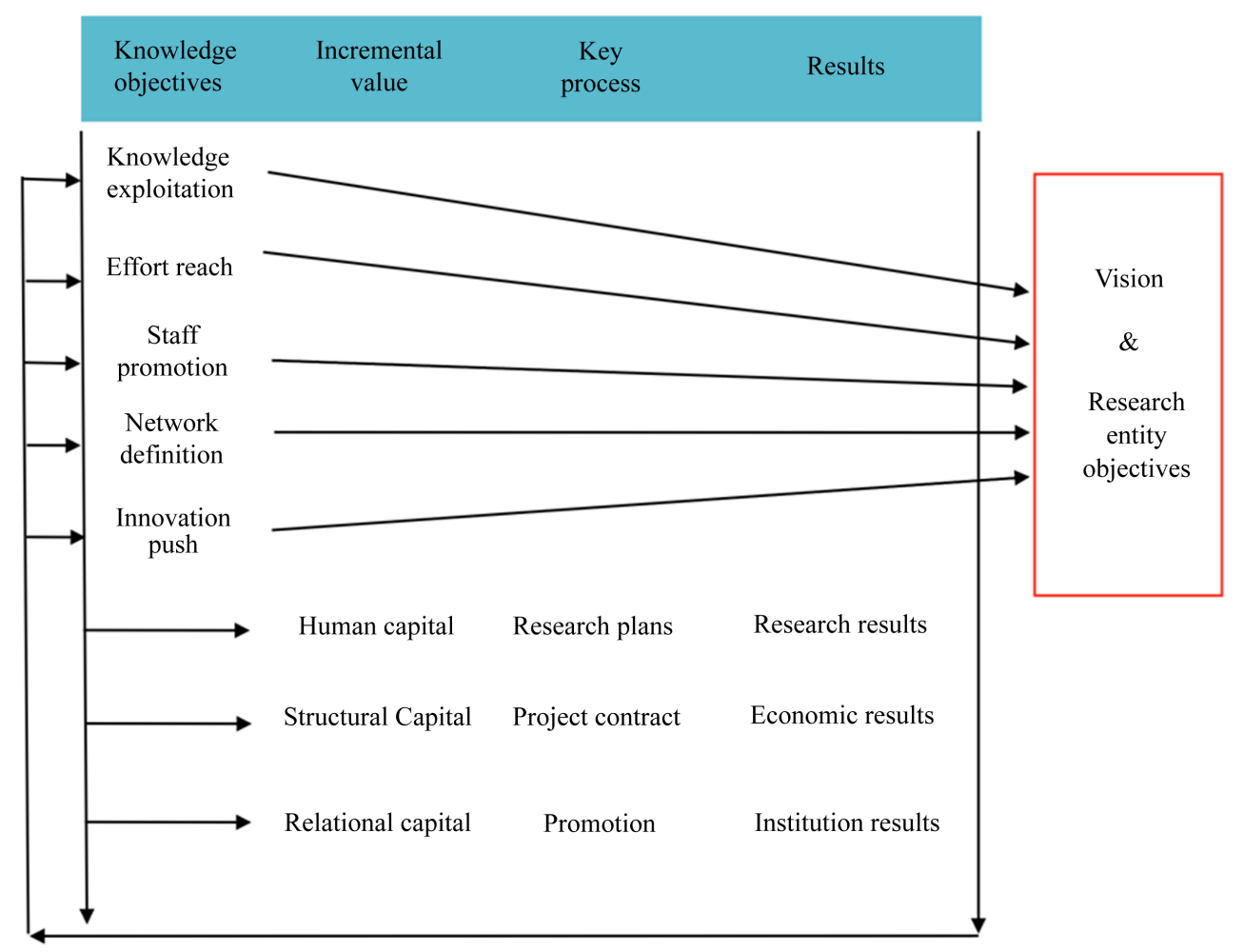

Figure 1. Knowledge creation and intellectual capital processes synoptic model of congruency; author's adaptation from different works of Manfred Bornemann, Karl-Heinz Leitner and Campbell Warden [46]-[48].

definition; innovation push. Considering the knowledge dimension as a crucial one for the development of research institution all these items can be observed and measured from the traditional accounting approach, following the classical paradigm: incremental potential value (as a projection, a target to refer to), a system of key process to account for and finally, according to the metric adopted, a system of result.

The third dimension involved in this system can be introduced considering the fact that knowledge objectives are embedded in the intellectual capital dimension as a relevant core value asset of a Research institution. Intellectual capital, as previously stated, can be categorized as human capital, structural capital and relational capital. This integrated system of values, considering the specific Research institution structure, identity and vision/ mission, can be managed and observed respectively in relation to the Research program, the Project contract and Management promotion. These items can be assumed as drivers of performance of the intellectual capital management that can be observed and measured in terms of:

- incremental value.

- key process.

- results.

in relation to research economic result and to the institution result in terms of, for instance, trust level and ethical behavior. The model must be understood as tool for an iterative system. Thus, clearly, vision, mission and objectives after the determination of the results have to be set against the initial ones and if it is the case, adjusted and newly determined. This model has to be flexible, assuming certain targets for the organizational development providing a framework for the use of intangibles in the value process. In fact, a fundamental step to consider for a research institution is that of structuring a creation process to use intangibles in value generation. In spite of specifying rigid targets, which can excessively constrain research activity, it would be better to choose wider goals for a more general direction. Consequently, new results can be considered an expression of interactions, intuitions and targeted research. In such a context, a clever exploitation of knowledge, crucial for the achievement of the institutions' results, requires existing documents and analysis on management and data to be internally accessible and shared. 
An adequately structured information system related to a management control model, focused, as suggested, on knowledge creation process as a result of the intellectual capital management, facilitates the individual access to the current knowledge and promotes its change inside the organization in order to share competences. Furthermore, it improves the creative strength, avoiding simultaneously parallel activities and internal competition. That is why structuring a network, promoting improving and exploiting the staff's professional skills, can be regarded as the essential elements of success.

To safeguard its own competitiveness, an institution should make an effort to achieve excellence, concentrating on those fields where it is the best and could even become leader, encouraging innovation and making knowledge and skills available inside and outside the sector, so as to earn flexibility for the research and to improve the reputation and social acceptation of the institution. Key processes include research programs, project contracts and management promotion. Each project is defined as a container of short-term tasks. It is possible to monitora part of the resource program dedicated to the project innovativeness. In this case, the aspect concerning technological transfer to the industrial process, if this was in the Institution's goals, aims at achieving research success both in the short run and in the long run. Therefore, the intellectual capital report is produced, in many cases, to consider the association among indicators and to illustrate how knowledge objectives are implemented. Consequently, following a certain profile the intellectual capital report becomes an accountability specific instrument where indicators are assigned to the model elements in the individual sections.

Abstraction is useful to schematize the recurrences proposed in complex and different dimensions of managerial control, in order to synoptically represent an integrated approach to intellectual capital management. The model, therefore, could be useful for any other specific characterization motivated by the context to be examined.

\section{Intellectual Capital Report and Accountability in Sicilian Research Structures}

The decreasing trend in financial public support of research and teaching activity, suggests a new management approach which gives more attention to the economic exploitation of knowledge resources generated and in general to intangible assets. As a consequence, the University and more specifically its departmental structure, more and more often, is involved in the implementation and improvement of strategies focusing on technological transfer and on the relationship university/society/economic world, looking simultaneously at the industrial and economic exploitation of research results and at financing all academic branches that all together generate the evolution of the delicate knowledge system [50]. Consequently the two needs of control and accountability develop together and overlap regarding the management problem as an element of propulsion, even with respect to investments feeding and to stakeholders. Therefore, value creation, through the research and the technological transfer system becomes an occasion to analyze, investigate and benchmark with best practices generating an environment where knowledge sharing and knowledge protection alternate and integrate in the prospect of improvement. The EU's “Lisbon strategy” guidelines suggest that EU members structure their policies and networks for the construction of Knowledge society.

More specifically, to achieve effectiveness, the way to give body to technological transfer and academic spin off must be identified; the way to make research institutions and university departments ideally converged. This research (that has to be regarded as the first step of a national evaluation route), presents an analysis conducted while working on the project called ReSInT (Rete Siciliana innovazione tecnologica-Sicilian network for technological innovation) promoted in Sicily by the Regional aldermanship for industry, carried out by IPI (Institute for Industrial Promotion), “http://www.censis.it/” Censis and "http://www.unioncameresicilia.it/” Unioncamere Sicilia. The project is meant to improve economic and productive knowledge and competence assets in Sicilian economic and productive systems, thanks to the involvement of knowledge producers (Universities, public and private research centers), innovative processes facilitators (Development Agency, Scientific and Technological parks, Business Innovation Centers, Services Centers, Chambers of Commerce, Entrepreneurs Associations, Public Administration) and final developers (small and medium sized firms).

More specifically, this study, after considering the logic that inspires or should inspire models for the evaluation of knowledge creation and accountability through the intangible assets of Academic departments and research centers, illustrates the situation concerning immaterial resources management tools diffusion. Furthermore, the study empirically analyzes the conditions in which university research departments and research centers act, trying to understand whether and in what way, managerial logics are applied to intangibles in common 
praxis. As already mentioned, besides the project, speculatively, the total amount of research entity data has been evaluated and related to the existence of Intellectual capital report, aiming at the activity of programming and controlling and, or more generally, to demonstrating accountability. The analysis approach employed in this study has, therefore, used the project Resint survey, trying to identify which is the best structure to understand knowledge flows inside the organization, verifying the existence and the employment of instruments to check the accountability of the carried out activity, to analyze the level of anticipated model creation of instruments with respect to their usage and to examine the use of instruments, of planning and controlling to manage intangibles and human capital, able to relate to accountability instruments.

The analysis carried out has had as its subject research institutions located in the Regione Siciliana and more specifically all the 89 research entities covering the western side of Sicily and the 84 present in the eastern part.

From analysis conducted on the western side, only 5 structures out of 89 (5.62\%) permanently adopt reports on the activity carried out (Figure 2).

As far as eastern Sicily is concerned, only 3 structures on 84 (3.57\%) adopt accountability instruments to report on the carried out activity (Figure 3). Notwithstanding this, none of these entities create forecast models with respect of their use, even if one of them uses planning and controlling instruments, to manage intangibles and human capital, coupled with the accountability system.

Actually, a rational use of knowledge means should provide the arrangement of accountability systems and reports with an adequate architectureable to integrate and create a bond with planning and controlling instruments to manage intangibles and human capital. This is the only way that would improve the results of this survey which highlights, instead, that on 173 state and private research centers, only 8 adopt accountability system as here below pointed out by the following chart (Figure 4).

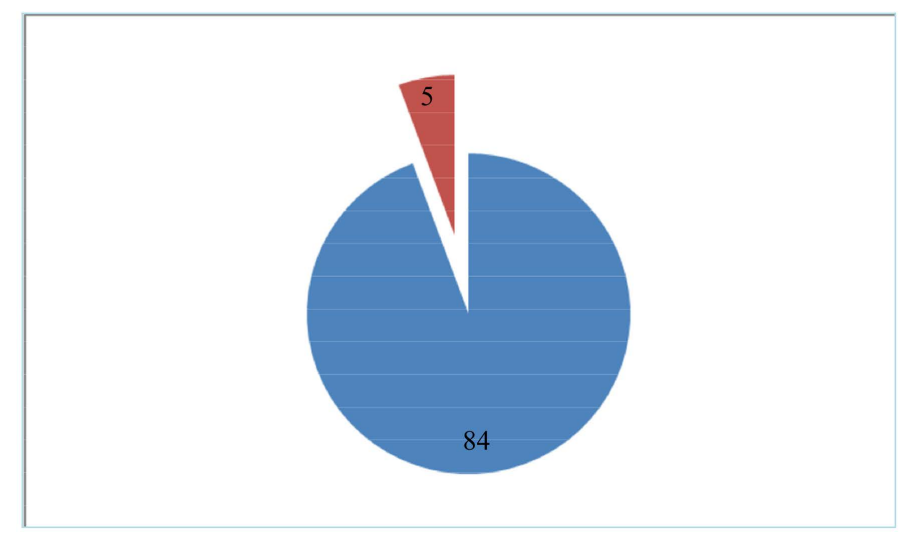

Figure 2. Number of structures that in western Sicily adopt accountability systems.

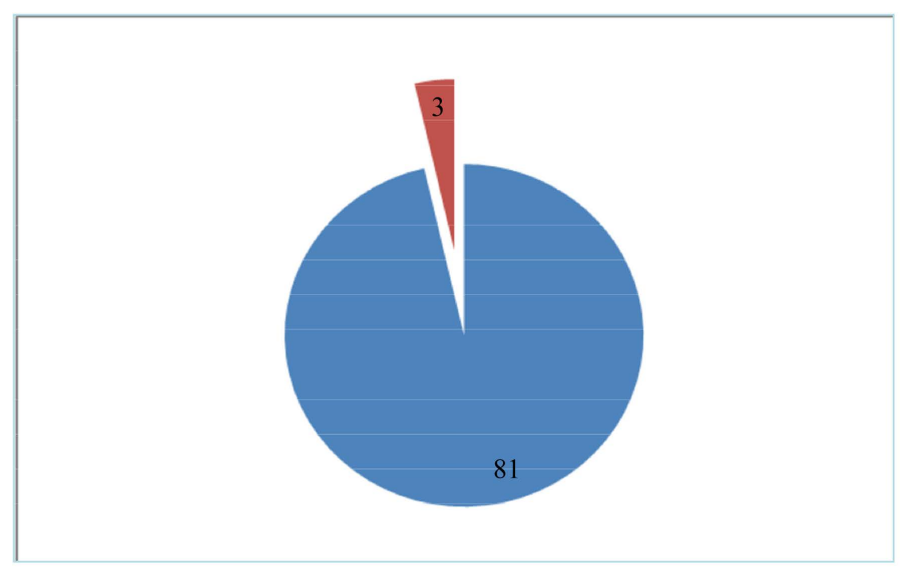

Figure 3. Number of structures in eastern Sicily adopting accountability systems. 


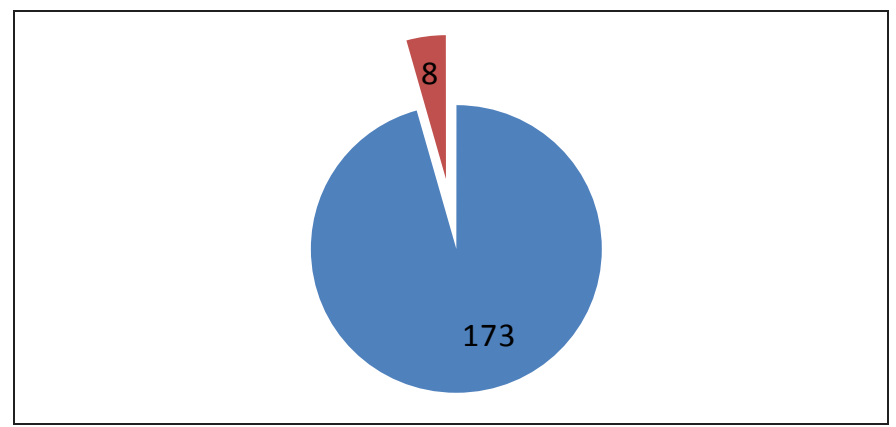

Figure 4. Number of structures in eastern Sicily adopting accountability systems.

\section{Results, Analysis and Final Remarks}

The analysis conducted involves the total number of research institutions in Sicily (173) reflecting, therefore, effectively its complex situation. Research entities even if internationally outstandingly evolved, or high quality and related to multinational industries, have not developed the need to consider the knowledge creation process at the same level as any other productive process yet and therefore, they have not developed specific methodologies for a representation of Intangibles and intellectual capital functional to control and accountability purposes. Among the 173 institutions, only 8 have effectively adopted an accountability system for intangibles management and evaluation. All of those research entities have a private sponsorship; among these 8 institutions, 25\% are made up of private units (2). $7.5 \%$ (7) of the institutions adopt a report for external accountability aims, while just $12.5 \%$ (1) use the report for both management and accountability. The data collected emphasize that intangibles are evaluated principally when the research institution has relevant relations with private financing. The private sector asks for accountability. Thus, the need for accountability and its logic could invert, or at least adjust, today's trend, becoming a means to involve even the private sector in the investment process of public research. As explained, the abstraction path that leads to the identification of the items to measure, to monitor and to report on, could be useful to define, as a synoptic model of congruency and used, as represented in Figure 2. This synoptic model could be used as a possible methodological tool, as a driver for the application of concepts like planning, controlling and generating accountability in relation to knowledge creation and intellectual capital management.

\section{References}

[1] Davis, S. and Meyer, C. (2000) Future Wealth. Harvard Business School Press, Boston.

[2] Pfeffer, J. (1994) Competitive Advantage through People Unleashing the Power of the Workforce. Harvard Business School Press, Boston.

[3] Von Krogh, G., Ichijo, K. and Nonaka, I. (2000) Enabling Knowledge Creation. How to Unlock the Mystery of Tacit Knowledge and Release the Power of Innovation. Oxford University Press, Inc., New York.

[4] Sullivan, P.H. (1998) Profiting from Intellectual Capital Extracting Value from Innovation. John Wiley \& Sons, Inc., New York.

[5] Kale, P., Singh, H. and Perlmutter, H. (2000) Learning and Protection of Proprietary Assets in Strategic Alliances: Building Relational Capital. Strategic Management Journal, 21, 217-237. http://dx.doi.org/10.1002/(SICI)1097-0266(200003)21:3<217::AID-SMJ95>3.0.CO;2-Y

[6] Chu, P.Y., Lin, Y.L., Hsiung, H.H. and Liu, T.Y. (2006) Intellectual Capital: An Empirical Study of ITRI. Technological Forecasting \& Social Change, 73, 886-902. http://dx.doi.org/10.1016/j.techfore.2005.11.001

[7] Gibbons, M., Limoges, C. and Nowotny, H. (1994) The New Production of Knowledge. Pinter Publishers, London and New York.

[8] Johanson, U., Martensson, M. and Skoog, M. (2001) Measuring to Understand Intangible Performance Drivers. European Accounting Review, 10, 407-437. http://dx.doi.org/10.1080/09638180126791

[9] Nonaka, I. and Nishiguchi, T. (2001) Knowledge Emergence. Social Technical and Evolutionary Dimension of Knowledge Creation. Oxford University Press, Inc., New York. 
[10] Steward, T. (1997) Intellectual Capital. The Wealth of Organizations, London.

[11] Lev, B. (1999) The Inadequate Public Information on Intellectual Capital and Its Consequences. Working Paper, International Symposium: Measuring and Reporting Intellectual Capital: Experiences, Issues, and Prospects, Amsterdam. (Unpublished)

[12] Kaplan, R.S. and Norton, D.P. (2001) The Strategy-Focused Organization. Harvard Business School Press, Boston.

[13] Jensen, R. (1999) The Dream Society: How to Transform the Coming Shift from Information to Imagination Will Transform Your Business. McGraw-Hill, New York.

[14] Nonaka, I. (1991) The Knowledge Creating Company. Harvard Business Review, 69, 96-104.

[15] Teece, D. (2000) Managing Intellectual Capital. Oxford University Press, Oxford.

[16] Bonaccorsi, A. and Daraio, C. (2007) University as Strategic Knowledge Creators: Some Preliminary Evidence. In: Bonaccorsi, A. and Daraio, C., Eds., Universities and Strategic Knowledge Creation, Edward Elgar, Cheltenham.

[17] Gulbransen, M. and Slipersæter, S. (2007) The Third Mission and the Entrepreneurial University Model. In: Bonaccorsi, A. and Daraio, C., Eds., Universities and Strategic Knowledge Creation, Edward Elgar, Cheltenham, 112-143. Bahara, N. (2001) Competitive Knowledge Management. Palgrave, Hampshire and New York.

[18] Bonaccorsi, A. and Piccaluga, A. (1994) A Theoretical Framework for the Evaluation of University-Industry Relationships. R\&D Management, 24, 154-169.

[19] Rudolph, B. and Leitner, K.H. (2002) Research Organisations Discover Their Intellectual Capital: Experiences of the Organisations DLR and ARC and the Potential for Comparing IC Measures. Paper Prepared for the Conference "The Transparent Enterprise. The Value of Intangibles”, Autonomous University of Madrid, Ministry of Economy, 25-26 November 2002, Madrid, Spain.

[20] Buckman, R.H. (1998) Knowledge Sharing at Buckman Labs. Journal of Business Strategy, 19, 11-15. http://dx.doi.org/10.1108/eb039903

[21] Arnold, E., Rush, H., Bessant, J. and Hobday, M. (1998) Strategic Planning in Research and Technology Institutes. $R$ \& D Management, 28, 89-100. http://dx.doi.org/10.1111/1467-9310.00085

[22] Albert, S. and Bradley, K. (1997) Managing Knowledge: Experts, Agencies and Organizations. Cambridge University Press, Cambridge. http://dx.doi.org/10.1017/CBO9780511582486

[23] Sullivan, P.H. (2001) Value-Driven Intellectual Capital: How to Convert Intangible Corporate Assets into Market Value. John-Wiley \& Sons, Inc., New York.

[24] Lev, B. (2001) Intangibles Management, Measurement, and Reporting. Brookings Institution Press, Washington DC.

[25] Guthrie, J., Ricceri, F. and Dumay, J. (2012) Reflections and Projections: A Decade of Intellectual Capital Accounting Research. British Accounting Review, 44, 68-82. http://dx.doi.org/10.1016/j.bar.2012.03.004

[26] Bounfour, A. (2013) The Management of Intangibles: The Organization’s Most Valuable Assets. Routledge, London and New York.

[27] Bounfour, A. (2011) Le Capital Organisationnel, Principes, Enjeux, Valeur. Springer, Paris. http://dx.doi.org/10.1007/978-2-8178-0241-1

[28] Canibano, L., Garcia-Ayuso, M. and Sanchez, M.P. (1999) Accounting for Intangibles: A Literature Review. Journal of Accounting Literature, 19, 102-130.

[29] Marr, B., Ed. (2005) Perspectives on Intellectual Capital. Multidisciplinary Insights into Management, Measurement and Reporting. Elsevier, Oxford.

[30] Parker, L. and Guthrie, J. (2009) Championing Intellectual Pluralism. Accounting, Auditing \& Accountability Journal, 22, 5-12. http://dx.doi.org/10.1108/09513570910922980

[31] Sveiby, K.E. (1997) The New Organizational Wealth: Managing and Measuring Knowledge-Based Assets. BerrettKoehler, San Francisco.

[32] Edvinsson, L. and Malone, M. (1997) Intellectual Capital, Realizing Your Company’s True Value by Findings Its Hidden Brainpower. Harper Business, New York.

[33] Lev, B. and Mintz, S.L. (1999) Seeing Is Believing: A Better Approach to Estimating Knowledge Capital. CFO Magazine, 15, 29-37.

[34] Mouritsen, J., Larsen, H.T. and Bukh, P.N.D. (2001) Intellectual Capital and the Capable Firm: Narration, Visualization and Numbering for Managing Knowledge. Accounting Organizations and Society, 26, 735-776. http://dx.doi.org/10.1016/S0361-3682(01)00022-8

[35] Bornemann, M. and Alwert, K. (2007) The German Guideline for Intellectual Capital Reporting: Method and Experiences. Journal of Intellectual Capital, 8, 563-576. http://dx.doi.org/10.1108/14691930710830756 
[36] Dumay, J.C. (2009) Intellectual Capital Measurement: A Critical Approach. Journal of Intellectual Capital, 10, 190210. http://dx.doi.org/10.1108/14691930910952614

[37] An, Y., Davey, H. and Eggleton, I.R.C. (2011) Towards a Comprehensive Theoretical Framework for Voluntary IC Disclosure. Journal of Intellectual Capital, 12, 571-585. http://dx.doi.org/10.1108/14691931111181733

[38] Atkinson, A.A., Waterhouse, H.H. and Welles, R.B. (1997) A Stakeholder Approach to Strategic Performance Management. Sloan Management Review, 38, 25-37.

[39] Bukh, P.N., Johansen, M.E. and Mouritsen, J. (2002) Multiple Integrated Performance Management Systems: IC and BSC in a Software Company. Singapore Management Review, 24, 21-33.

[40] De Gooijer, J. (2000) Designing a Knowledge Management Performance Framework. Journal of Knowledge Management, 4, 303-310.

[41] Dodgson, M. and Hinze, S. (2000) Indicator Used to Measure the Innovation Process: Defects and Remedies. Research Evaluation, 9, 101-114. http://dx.doi.org/10.3152/147154400781777368

[42] Dumany, J.C. (2009) Intellectual Capital Measurement: A Critical Approach. Journal of Intellectual Capital, 10, 190210. http://dx.doi.org/10.1108/14691930910952614

[43] Foray, D. (2000) Characterizing the Knowledge Base: Available and Missing Indicators. In: OECD, Ed., Knowledge Management in the Learning Society, OECD, Paris, 239-257.

[44] Cook, S.D.N. and Brown, J.S. (1999) Bridging Epistemologies: The Generative Dance between Organizational Knowledge and Organizational Knowing. Organization Science, 10, 381-400. http://dx.doi.org/10.1287/orsc.10.4.381

[45] Roessner, D. (2000) Quantitative and Qualitative Methods and Measures in the Evaluation of Research. Research Evaluation, 9, 125-132. http://dx.doi.org/10.3152/147154400781777296

[46] Leitner, K.H. and Warden, C. (2003) Managing and Reporting Knowledge-Based Resources and Processes in Research Organizations: Specifics, Lessons Learned and Perspectives. Management Accounting Research, 15, 33-51. http://dx.doi.org/10.1016/j.mar.2003.10.005

[47] Leitner, K.H. (2005) Managing and Reporting Intangibles Assets in Research Technology Organizations. R \& D Management, 35, 125-136. http://dx.doi.org/10.1111/j.1467-9310.2005.00378.x

[48] Koch, G., Leitner, K.H. and Bornemann, M. (2000) Measuring and Reporting Intangible Assets and Results in a European Contract Research Organization. Proceedings of the Joint German-OECD Conference on Benchmarking Industry-Science Relationships, Berlin, 16-17 October 2000.

[49] Leitner, K.H. (2004) Intellectual Capital Reporting for Universities: Conceptual Background and Application for Austrian Universities. Research Evaluation, 13, 129-140. http://dx.doi.org/10.3152/147154404781776464

[50] Holland, J. (2004) Corporate Intangibles, Value Relevance and Disclosure Content. Institute of Chartered Accountants of Scotland, Edinburgh. 